\title{
POSITIONING DAN SEGMENTASI PASAR PRODUK SARANG INFUS (SARUNG TANGAN INFUS) DI RUMAH SAKIT PERSYARIKATAN MUHAMMADIYAH DAERAH SURABAYA-SIDOARJO
}

\author{
Putri Lisdiyanti, Fatma Aula Nursyifa, Riskiatul Mutamima, Finka Yuanita, Gita Marini \\ Universitas Muhammadiyah Surabaya
}

\begin{abstract}
Occurrence at risk of infection, risk of injury and stress of hospitalization are three events that often occur in children who are hospitalized with infusion. During this time the efforts of these events have only been overcome by the installation of a buffer on the hand and fixation with gauze rolls that are looped on the child's arm only so that this can only reduce the risk of infection. Provision of infusion nest products (infusion gloves) is an effort to prevent and reduce the occurrence of these three events. Infusion nest products are creative innovations that have been made because so far there are no similar products in hospitals.

Marketing research on consumers of nest infusion products is carried out to determine the potential of the market and the behaviors that develop in consumers so that clear information about the customers of infusion nest products can be obtained, especially in hospitals that are sheltered by Muhammadiyah Hospital in Surabaya-Sidoarjo. One of the important data to analyze is data about certain segments of the customer and how the infusion nest producers are able to place their product position on consumer perceptions. This is very important to determine the marketing strategy. appropriate.

Customers from hospitals that are in large numbers in Surabaya and scattered are certainly not possible to analyze all, so we need a marketing research procedure by taking samples. samples designed to obtain data on demographic characteristics, psychography, behavior and consumer preferences. In addition, information about perceptual maping from consumers on infusion nest products is needed to find out the map of respondents' perceptions of the nest infusion product attributes. From consumer preference data on marketing attributes of nest infusion products customer segmentation can be done to obtain information about groups of customers based on the choice of the most important attributes. In addition, each segment can be described the characteristics of psychography, demographics and behavior to see the characteristics of each segment. The data about positioning provides information on product position in customer perceptions based on marketing attributes that are superior to infusion nest products.

From the data obtained from filling out the questionnaire after validation through Focus Group Discussion with child nurse nurses in two Muhammadiyah Hospital (RS) namely Siti Khodijah Hospital Along and RSIA Aisyiah Pacarkeling Surabaya it was found that infusion nest customers, can be grouped into 2 groups with preference characteristics, demographics, psychography, and different behaviors. While the positioning of infusion nest products in consumer perceptions is still relatively close to a number of superior attributes, such as there are no similar products on the market, products are comfortable for children, products can make it easier for nurses to observe infusion conditions in accordance with hospital accreditation but prices offered by producers can increase the cost of installing IVs so that they can only be temporarily reached by patient patients non BPJS users.
\end{abstract}




$\begin{array}{ll}\text { Keywords } & : \text { Infusion nest products, positioning } \\ \text { Correspondence to } & \text { : gita.ners82@gmail.com }\end{array}$

\begin{abstract}
ABSTRAK
Kejadian Resiko Infeksi, resiko cidera dan stress hospitalisasi merupakan tiga kejadian yang seringkali terjadi pada anak yang mengalami rawat inap yang terpasang infus. Selama ini upaya kejadian tersebut hanya diatasi dengan pemasangan penyangga pada tangan dan fiksasi dengan kasa gulung yang dilingkarkan pada lengan anak saja sehingga hal ini hanya dapat mengurangi kejadian resiko infeksi saja. Pemberian produk sarang infus (sarung tangan infus) merupakan upaya untuk mencegah dan mengurangi terjadinya ketiga kejadian tersebut. Produk sarang infus merupakan inovasi kreatif yang telah dibuat karena selama ini tidak ada produk serupa yang ada di rumah sakit.

Riset pemasaran terhadap konsumen produk sarang infus dilakukan untuk mengetahui potensi - potensi pasar dan prilaku - prilaku yang berkembang pada konsumen sehingga dapat diperoleh informasi yang jelas tentang pelanggan produk sarang infus khususnya di Rumah Sakit yang bernaung pada persyarikatan Muhammadiyah di Surabaya-Sidoarjo. Salah satu data yang penting untuk di analisis adalah data tentang segmen - segmen tertentu dari pelanggan serta bagaimana produsen sarang infus tersebut mampu menempatkan posisi produknya pada persepsi konsumen. Hal ini sangat penting untuk menentukan strategi pemasaran. yang sesuai.

Pelanggan dari rumah sakit yang jumlahnya banyak di Surabaya dan terpencar - pencar tentunya tidak mungkin kita analisis semua, sehingga diperlukan prosedur riset pemasaran dengan melakukan pengambilan sampel. sampel yang didesain untuk men -dapatkan data tentang karakteristik demografi, psikografi, prilaku dan preferensi konsumen. Selain itu informasi tentang perceptual maping dari konsumen terhadap produk sarang infus sangat diperlukan untuk mengetahui peta persepsi responden terhadap atribut produk sarang infus. Dari data preferensi konsumen terhadap atribut pemasaran produk sarang infus dapat dilakukan segmentasi pelanggan untuk memperoleh informasi tentang kelompok - kelompok pelanggan berdasarkan pilihan terhadap atribut yang paling dipentingkan. Selain itu masing - masing segmen dapat dideskripsikan karakteristik psikografi, demografi dan prilakunya untuk melihat ciri - ciri yang dimiliki masing masing segmen. Adapun data tentang positioning memberikan informasi posisi produk dalam persepsi pelanggan berdasarkan atribut pemasaran yang diunggulkan pleh produk sarang infus.

Dari data yang diperoleh dari pengisian kuisioner setelah validasi melalui Fokus Group Discussion dengan perawat perawat anak di dua Rumah sakit (RS) Muhammadiyah yaitu RS Siti Khodijah Sepanjang dan RSIA Aisyiah Pacarkeling Surabaya didapatkan bahwa pelanggan sarang infus, dapat dikelompokkan menjadi 2 kelompok dengan karakteristik preferensi, demografi, psikografi, dan prilaku yang berbeda - beda. Sedangkan positioning produk sarang infus dalam persepsi konsumen masih relatif berdekatan untuk beberapa atribut yang diunggulkan, seperti belum ada produk serupa di pasar, produk nyaman dipakai oleh anak-anak, produk dapat memudahkan perawat untuk mengobservasi kondisi infus sesuai dengan tujuan akreditasi rumah sakit namun harga yang ditawarkan produsen dapat meningkatkan biaya pasang infus sehingga untuk sementara hanya dapat dijangkau oleh pasien pasien non pengguna BPJS.
\end{abstract}

$\begin{array}{ll}\text { Kata kunci } & \text { : produk sarang infus, positioning,segmentasi } \\ \text { Korespondensi } & \text { : gita.ners82@gmail.com }\end{array}$

Jurnal Balance 


\section{PENDAHULUAN / INTRODUCTION}

Kejadian tidak menyenangkan dalam Rumah Sakit mengakibatkan trauma pada anak. Salah satu kejadian yang tidak menyenangkan bagi anak adalah pemasangan infus. Selain itu pemasangan infus dapat mengakibatkan stress hospitalisasi juga dapat mengakibatkan resiko infeksi dan Resiko Injury. Resiko Injury dapat mengancam kesehatan keamanan anak yang belum bisa melindungi dirinya sendiri dan membuat orangtua merasa cemas serta menyesal, tetapi sebenarnya cedera ini dapat dicegah (National Safety Council, 2006).Cedera adalah penyebab kematian yang mewakili salah satu dari penyebab yang paling penting dari morbiditas dan mortalitas pediatri yang dapat dicegah (Arvin, Behrman Kliegman.2000).

Angka kesakitan anak di Indonesia berdasarkan Survei Kesehatan Nasional (Susenas) tahun 2010 yang dikutip oleh Apriany (2013), di daerah perkotaan menurut kelompok usia 0-4 tahun sebesar 25,8\%, usia 5-12 tahun sebanyak 14,91\%, usia 13-15 tahun sekitar 9,1\%, usia 16-21 tahun sebesar 8,13\%. Angka kesakitan anak usia 0-21 tahun apabila dihitung dari keseluruhan jumlah penduduk adalah $14,44 \%$. Anak yang dirawat di rumah sakit akan berpengaruh pada kondisi fisik dan psikologinya, hal ini disebut dengan hospitalisasi.

Pemasangan infus pada anak-anak selain dapat menyebabkan hospitalisasi juga dapat menyebabkan resiko infeski dan resiko injury. Salah satu resiko infeksi yang dapat terjadi di rumah sakit adalah resiko infeksi nosokomial. Infeksi nosokomial atau infeksi yang diperoleh dari rumah sakit salah satunya adalah flebitis. Phlebritis terjadi akibat adanya inflamasi vena yang disebabkan oleh iritasi kimia (bahan teertentu) maupun mekanik. Angka standar phlebrits yang direkomendasikan oleh INS (Infusion Nurse Society) adalah 5\%. Kasus kejadian infeksi nosokomial (flebitis) sebagian besar tidak dilaporkan sehingga angka insidensnya bervariasi. Insidens tromboflebitis akibat pemasangan infus vena perifer sangat bervariasi karena perbedaan definisi, desain penelitian, pemilihan pasien, dan lama follow up. 3 Machado, et al, (2008) melaporkan angka kejadian flebitis pada anak sebesar $4,7 \%$, Jacinto, et al, (2014) 2,7\%, Abusafia, et al, (2015) 2,7\%, dan di Indonesia dilaporkan prevalensi flebitis sebesar 16,5\% (2013). Tindakan untuk pencegahan dini flebitis akibat pemasangan infus adalah dengan cara pembidaian. World Health Organization menggambarkan kejadian injurysebagai suatu peristiwa yang disebabkan oleh dampak dari suatu agen eksternal secara tiba-tiba dan dengan cepat menghasilkan kerusakan baik fisik maupun mental. Injurytersebut meliputi cedera lalu lintas, jatuh, terbakar, tenggelam, keracuganan, tergores, dan gigitan binatang ( Wong, Donna.L. 2004). Pemasangan infus dapat menimbulkan resiko tergoresnya bahaya injuryanak usia toddler (gesekan kulit, tergores, tersangkut pakaian, tersangkut tempat tidur,robekan palpebra). yaitu dengan memberikan informasi dan pengetahuan pada orangtua serta selalu waspada terhadap setiap gerak yang dilakukan oleh anak, memberikan alat bermain yang sesuai dan tidak membahayakan, serta melakukan pengawasan dengan memberi perhatian pada anak.

Saat ini hal yang dilakukan di rumahsakit untuk mencegah infeksi 
pemasangan infus pada anak kecil adalah membidai dengan spalek kecil dan perban. Dalam tindakan tersebut dapat mengurangi resiko infeksi tetapi tidak dapat mengurangi hospitalisasi pada anak dan resiko injury. Saat ini untuk mengurangi resiko injuri anak yang terpasang infus yaitu dengan memberikan informasi dan pengetahuan pada orangtua serta selalu waspada terhadap setiap gerak yang dilakukan oleh anak, memberikan alat bermain yang sesuai dan tidak membahayakan, serta melakukan pengawasan dengan memberi perhatian pada anak.

Dari masalah tersebut kami menawarkan produk "SARANG INFUS" belum pernah ada di pasaran dan memiliki permintaan pasar yang tinggi akibat angka kejadian hospitalisasi, resiko Infeksi dan antisipasi resiko kejadian injury. Bentuknya yang inovativ mampu mengurangi hospitalisasi akibat pemasangan infus, serta dilengkapi dengan fiksasi yang dapat mengurangi resiko infeski pada anak.

Pemahaman karakteristik konsumen sangat penting ketika seorang pebisnis memutuskan untuk menjadi peserta dalam strategi pemasaran dalam bisnis. Kotler/Amstrong (2005) mengatakan bahwa produsen tidak akan berhasil menarik semua pembeli dipasar industri maupun konsumen atau sekurang - kurangnya tidak akan berhasil menarik pembeli dengan cara yang sama .Hal ini terjadi karena pembeli itu jumlahnya banyak sekali jumlahnya dan terlalu terpencar - pencar. Selain itu sasaran yang tepat dalam membidik konsumen dan penentuan posisi dari bisnisnya akan menjadi pertimbangan yang menentukan kesuksesan dalam bisnis. Berdasarkan latar belakang inilah kemudian peneliti mencoba melakukan studi pemasaran tentang Positioning dan Segmentasi Pasar Produk Sarang Infus (Sarung Tangan Infus) di Rumah Sakit Persyarikatan Muhammadiyah daerah Surabaya-Sidoarjo. Berdasarkan survey dilapangan bahwa Rumah Sakit. Siti Khodijah yang berada di Kota Surabaya dan Rumah Sakit Ibu dan Anak Siti Aisyiah terdapat dua Rumah Sakit di Persyarikatan Muhammadiyah yang memiliki budaya kerja yang sama untuk perawat nya yang dapat digunakan sebagai sampel, serta dapat digunakan sebagai pembanding positioning RS sebagai konsumen sarang infus, yang menerima. pasien dengna BPJS dan Non BPJS.

\section{Kajian Teori}

Produk dapat diartikan sebagai hasil dari suatu aktivitas proses produksi. Dan hasil ini bisa berupa barang (goods) dan jasa (services), yang dapat dinikmati dan membantu konsumen dalam melaksanakan aktivitas sehari- hari. Pengertian produk menurut Kotler (2005), "Produk adalah suatu sifat yang kompleks baik dapat diraba maupun tidak dapat diraba, termasuk bungkus, warna, harga, prestise perusahaan dan pengecer produk tersebut hingga diterima pembeli untuk memuaskan kebutuhannya". Konsep produk merupakan acuan dan kerangka dasar pemikiran dalam mengamati dan mengidentifikasi suatu produk. Adapun penjelasan mengenai konsep produk menurut Philip Kotler (2005) adalah sebagai berikut : "Konsumen akan menyukai produk- produk yang memiliki kualitas, penampilan dan ciriciri yang sangat baik. Manajemen dalam organisasi yang berorientasi pada produk demikian memusatkan energi mereka untuk membuat produk yang baik dan terus menerus meningkatkan mutu produk tersebut “. Untuk merealisasikan produk perusahaan menyusun atribut - atribut yang akan mendukung terciptanya prototipe produk . Atribut - atribut tersebut berupa kualitas produk, fitur produk, rancangan produk, Merek produk, kemasan dan label produk. Lebih lanjut kualitas (Quality of Product) sendiri dapat dijelaskan lebih lanjut sebagai 
kinerja atau performa (performance), kemampuan unjuk kerja (comformance), keandalan (reliability), kemudahan untuk diperbaiki (repai -rability), tahan usia (durability) dan desain. Biasanya tidak semua komponen atribut dijadikan andalan (selling point) oleh perusahaan namun bagi produsen, terdapat satu atau lebih atribut yang menonjol (salient attribut) dari suatu produk.

Menurut Philip Kotler (2005)

keputusan yang berhubungan dengan pengembangan dan pemasaran berkaitan dengan suatu produk tertentu harus memperhatikan dan membahas variabel suatu produk.

\section{Perilaku Konsumen}

Menurut Paul Peter dan Jerry $C$. Olson (1996) perilaku konsumen merupakan interaksi dinamis antara pengaruh dan kognisi , perilkau dan kejadian disekitar kita yaitu tempat manusia melakukan pertukaran didalam hidup.

Dalam menganalisa perilaku konsumen tidak hanya menyangkut faktorfaktor yang mempengaruhi pengambilan keputusan yang menyertai pembelian, akan tetapi juga meliputi proses pengambilan keputusan yang menyertai pembelian. Dengan demikian memahami perilaku konsumen bukanlah suatu pekerjaan yang mudah karena banyaknya variabel yang mempengaruhi dan variabel-variabel tersebut saling berinteraksi. Karena itu Kotler (2006) beranggapan bahwa perilaku konsumen merupakan proses yang kompleks dan multidimensional.

Pemasar tidak hanya berhenti pada perilaku konsumen saja, namun juga perlu juga perlu mengkaitkannya dengan strategi pemasaran yang akan disusunnya. Mengenai faktor yang mempengaruhi perilaku konsumen dan keterkaitannya dengan strategi pemasaran ini, Coney menggambarkan dalam gambar 2.1 dibawah. Berdasarkan gambar dibawah terlihat bahwa ada 3 faktor yang yang menentukan perilaku konsumen yakni karaktertistik personal, karakteristik produk dan situasi konsumsi.

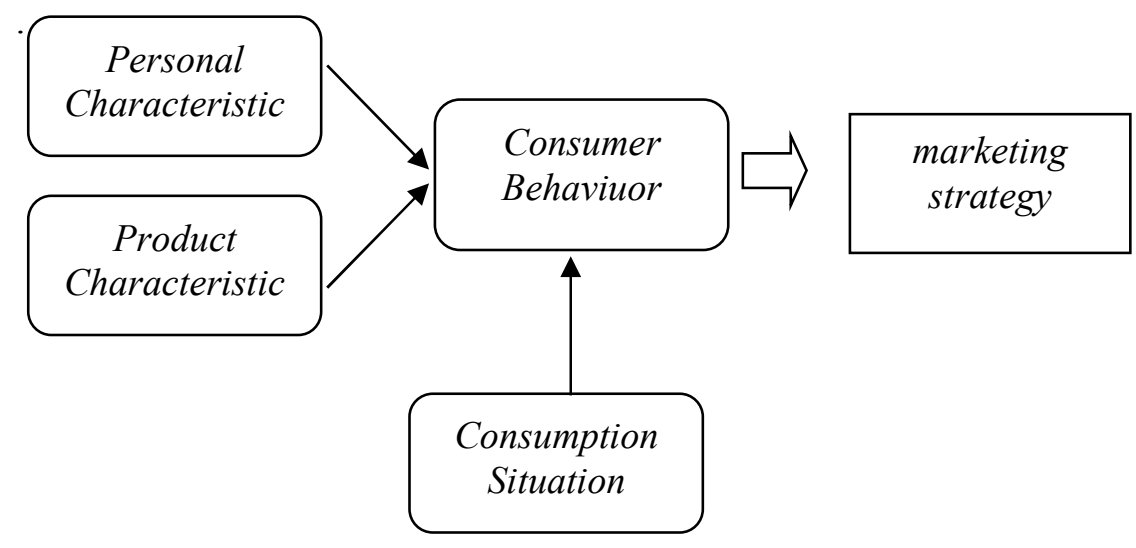

Gambar 2.1. Hubungan Perilaku Konsumen dan Strategi Pemasaran

Apabila perusahaan mampu memahami perilaku konsumen sehingga dapat memenuhi keinginan dan kebutuhan konsumen maka akan mendapatkan keuntungan yang cukup

$$
\begin{array}{lccr}
\text { besar dibanding } & \text { pesaingnya } & \text { karena } \\
\text { perusahaan dapat } & \text { menyusun } & \text { strategi } \\
\text { pemasaran yang tepat yang } & \text { dapat }
\end{array}
$$


memberikan kepuasan yang lebih baik dibanding pesaing.

\section{Segmentasi}

Segmentasi menurut Rhenald Kasali (2011) adalah proses mengkotak-kotakkan pasar yang heterogen kedalam kelompokkelompok potensial consumers yang memiliki kesamaan kebutuhan, kesamaan karakter atau tingkah laku yang memiliki respons yang sama dalam membelanjakan uangnya.

Tujuan utama segmentasi menurut Kotler (2005) adalah melayani konsumen lebih baik dan memperbaiki kompetitif perusahaan perusahaan akan lebih mudah melayani berbagai kebutuhan dan keinginan pasar. Secara umum segmentasi bermanfaat untuk meningkatkan posisi kompetisi perusahaan dan membedakan pelayanan yang lebih baik kepada konsumen. Segmentasi pasar perlu dilakukan karena pada umumnya pasar untuk suatu produk atau jasa mempunyai banyak perbedaan terutama pada kebutuhan, keinginan dan perbedaan daya beli konsumen.

Pemasaran konvensional mengatakan bahwa pemasaran massal (mass marketing) akan menimbulkan potensi pasar yang besar, biaya rendah, sehingga akan menghasilkan produk dengan harga rendah atau margin yang tinggi. Dalam pemasaran massal, filosofi yang mendasari adalah bahwa pasar yang luas diasumsikan hanya mempunyai satu kebutuhan yang umum.

Namun saat ini, pendekatan pemasaran massal tradisional yang ingin menguasai pasar yang luas menjadi tidak efektif, karena pemasar menjadi kesulitan untuk menguasai pasar yang luas dengan produk tunggal, Philip Kotler (2005). Bagaimanapun konsumen adalah kelompok yang luas dan sangat heterogen, sehingga harus dipertimbangkan untuk membagi pasar ke dalam kelompok yang lebih kecil berdasarkan kesamaannya.

Langkah pertama dalam melakukan strategi segmentasi adalah dengan menyeleksi pendekatan segmentasi yang sesuai dengan segmen yang ada di pasar. Ada dua pendekatan utama segmentasi menurut Rhenald Kasali (2011) yaitu pendekatan apriori dan pendekatan post-hoc.

\section{Syarat syarat Segmentasi Dapat Berdaya Guna}

1. Dapat diukur : sejauh mana besarnya pasar dan daya beli,profil segmen ini dapat diukur . sebagai contoh : dove yang melakukan segmentasi produk pada kalangan mahasiswa yang lebih mementingkan manfaat dan penampilan

2. Besar : Sejauh mana segmen ini cukup besar dan menguntungkan untuk dilayani.Suatu segmen harus merupakan nilai kelompok homogen besar yang memungkinkan dibuat strategi khusus untuk mereka.

3. Dapat dijangkau : Segmen harus dapat dijangkau dan dilayani secara efektif.Misalkan swalayan menemukan bahwa pelanggan terbesar mereka adalah kalangan ibu - ibu rumah tangga kelas menengah yang tinggal didalam kota.

4. Dapat dibedakan : Segmen - segmen dapat dipisahkansecara konseptual dan memberikan tanggapan yang berbeda terhadap elemen bauran pemasaran yang ada

5. Dapat dilaksanakan : Program program yang efektif dapat dirumuskan untuk menarik dan melayani segmen yang bersangkutan 


\section{Mengevaluasi Segmen Pasar}

Dalam mengevaluasi segmen pasar yang berbeda perusahaan harus memperhatikan tiga faktor yaitu :

\section{Ukuran dan pertumbuhan segmen}

Segmen yang potensial memiliki ukuran pertumbuhan yang tepat .Perusahaan besar sering mementingkan segmen yang memiliki volume penjualan besar dan sering meremehkan segmen yang kecil begitu pula sebaliknya untuk perusahaan kecil sehingga sering kali perusahaan kecil datang mengambil segmen yang yang kecil dan berkembang sehingga mampu menekan kemampu - labaan mereka

\section{2. daya tarik struktural segmen}

Suatu segmen mungkin memiliki ukuran dan petumbuhan seperti yang didambakan akan tetapi tidak menarik dilihat dari segi profitabilitas.Perusahaan harus menarik beberapa faktor struktural utama yang mempengaruhi kemenarikan segmen dalam jangka panjang .Contoh :segmen kurang menarik jika didalamnya sudah terdapat kompetitor kuat dan agresif atau harus diperhatikan ancaman dari adanya produk subtitusi atau pengganti.

\section{3. tujuan dan sumber daya perusahaan}

Jika suatu segmen itu besar,berkembang dan menarik secara struktural perusahaan akan mempertimbangkan sumber dayanya sendiri berkaitan dengan segmen tersebut.Beberapa segmen yang menarik akan hilang karena tidak seuai dengan tujuan jangka panjang perusahaan.

\section{Sasaran pemasaran}

Menetapkan target market adalah memilih segmen yang potensial dan yang akan dilayani. Hasil dari targeting adalah target market (pasar sasaran) yaitu satu atau beberapa segmen pasar yang akan menjadi fokus kegiatan pemasaran. Memfokuskan disini berarti pemasar harus berani memfokuskan kegiatannya kepada beberapa segmen saja dan mencari segmen mana yang mempunyai potensi untuk paling dipuaskan.

Untuk itu menurut Kotler (2005) perusahaan dapat mempertimbangkan lima pola dalam melakukan seleksi target market, seperti pada tabel 2.1. dibawah :

Tabel 2.1 : Lima Pola Pemilihan Target Pasar

\begin{tabular}{|l|l|l|l|l|l|l|l|l|l|l|l|l|l|l|l|}
\hline & \multicolumn{2}{l|}{$\begin{array}{l}\text { Singgle } \\
\text { segment } \\
\text { Conentration }\end{array}$} & \multicolumn{2}{l|}{$\begin{array}{l}\text { Selective } \\
\text { Specialization }\end{array}$} & \multicolumn{2}{l|}{$\begin{array}{l}\text { Product } \\
\text { Specialization }\end{array}$} & \multicolumn{2}{l|}{$\begin{array}{l}\text { Market } \\
\text { Specialization }\end{array}$} & \multicolumn{2}{l|}{$\begin{array}{l}\text { Full } \\
\text { Coverage }\end{array}$} \\
\hline & $\mathrm{M}_{1}$ & $\mathrm{M}_{2}$ & $\mathrm{M}_{3}$ & $\mathrm{M}_{1}$ & $\mathrm{M}_{2}$ & $\mathrm{M}_{3}$ & $\mathrm{M}_{1}$ & $\mathrm{M}_{2}$ & $\mathrm{M}_{3}$ & $\mathrm{M}_{1}$ & $\mathrm{M}_{2}$ & $\mathrm{M}_{3}$ & $\mathrm{M}_{1}$ & $\mathrm{M}_{2}$ & $\mathrm{M}_{3}$ \\
\hline $\mathrm{P}_{1}$ & & & & & & & & & & & & & & & \\
\hline $\mathrm{P}_{2}$ & & & & & & & & & & & & & & & \\
\hline $\mathrm{P}_{3}$ & & & & & & & & & & & & & & & \\
\hline & & & & & & & & & & & & & & & \\
\hline
\end{tabular}

Dari tabel 2.1 dapat dijelaskan sebagai berikut :

1. Single Segment Concentration.

Perusahaan memilih satu segmen saja.
2. Selective Specialization. Perusahaan menyeleksi beberapa segmen sinergi, segmen yang dipilih mungkin tidak saling 
berhubungan atau membentuk tetapi masing-masing segmen menjanjikan uang

3. Product Specialization. Perusahaan berkonsentrasi membuat sebuah produk khusus atau tertentu.

4. Market Specialization. Dalam strategi ini perusahaan berkonsentrasi melayani berbagai kebutuhan dalam kelompok tertentu

5. Full Market Coverage. Perusahaan berusaha melayani semua kelompok dengan produk yang dibutuhkan. Namun hanya perusahaan besar yang bisa melakukannya.

\section{Positioning}

Positioning menurut Rhenald kasali (2001) merupakan proses bagaimana konsumen memproses informasi dalam otaknya, manusia memproses informasi dengan sensai yang diterima. Proses berpikir ini melibatkan sesuatu yang disebut persepsi. Persepsi inilah yang menjadi bahan perhatian para ahli positioning. Sehingga positioningb merupakan suatu jendela persepsi dalam otak konsumen. Dalam hal ini ada lima informasi yang disimpan dalam pusat - pusat informasi konsumen yaitu :

1. Nama merk -merk tertentu

2. Karakteristik merk tersebut (biasanya dinyatakan dalam bentuk atribut)

3. Iklan - iklan mengenai merk tersebut

4. Kategori produk

5. Hasil evaluasi konsumen terhadap merk merk tertentu dan iklannya

Philip Kotler (2005) menuliskan bahwa positioning adalah tindakan yang dilakukan pemasar untuk membuat citra produk dan hal-hal yang ingin ditawarkan kepada pasarnya berhasil memperoleh posisi yang jelas dan mengandung arti dalam benak sasaran konsumennya.

\section{Perceptual Mapping}

Definisi perceptual mapping atau bisa disebut brand or product mapping menurut sebuah lembaga penelitian surveysite adalah suatu metode untuk menganalisa dan memahami persepsi konsumen terhadap sebuah produk. Konsep persepsi sendiri menurut Mowen (1995) yang dikutip oleh Kasali (2011) merupakan "suatu proses dimana individu-individu terekspos oleh informasi dan menyediakan kapasitas prosesor yang lebih luas untuk menginterpretasikan informasi tersebut".

$$
\text { Definisi persepsi menurut Myers }
$$

(1996) adalah "suatu proses untuk mengartikan sensasi dengan memberikan gambar-gambar dan hubungan-hubungan asosiasi didalam memori untuk menafsirkan dunia diluar dirinya”.

Kunci terpenting dalam persepsi menurut Rhenald Kasali (1998) adalah bahwa manusia menyimpan informasi dalam bentuk hubungan asosiatif, dan hubungan asosiatif itu membantu manusia menginterpretasikan dunia di sekitarnya.

Produk yang dipersepsikan disini adalah produk yang dapat diidentifikasi oleh konsumen sebagai contoh, produk konsumen (customers products) seperti pasta gigi, sabun, sampo, makanan, mobil dll., produk industri (industrial products) seperti computer, peralatan berat dll., institusi (perusahaan, hotel, restoran, rumah sakit, majalah dll.), aktifitas (liburan, olahraga, film d1l), orang (bintang film, penyanyi, kandidat politik dll).

Product mappping menghasilkan sebuah gambar atau peta dari pasar. Peta ini merupakan gambaran bagaimana sebuah produk dirasakan pada ingatan konsumen terhadap ciri khas atau atribut seperti reputasi, merek, harga atau kualitas. Hasil pemetaan posisi juga menunjukkan bagaiman posisi persaingan produk terhadap pesaingnya pada benak konsumen dan dapat memberi informasi untuk meningkatkan posisi pasar dan nilai penjualan. 
Peta posisi juga memberikan sumbangan yang sangat berharga dalam pengambilan keputusan. Beberapa aplikasi penting dalam dunia pemasaran antara lain :

\section{Market Description and Segmentation}

Peta produk (product maps) dapat mengidentifikasi perusahaan, produk atau service mana yang menjadi pesaing dalam pasar. Dalam peta juga memberikan gambaran kondisi pasar yang jelas dan memberi saran mengenai strategi segmentasi yang mungkin dapat dilakukan.

2. Identifying Product Weaknesses

Peta menunjukkan bagaimana produk dilihat atau dinilai dalam atribut dan dimensi tertentu. Analisa dari peta dapat mengetahui kelemahan dan kekurangan produk kita maupun pesaing, sehingga dapat memberi saran pengiklanan (advertising) baru dan atau strategi positioning.

3. Concept Development and Evaluation

Pengusulan peluncuran produk baru dapat dibangun dan dievaluasi dengan contohnya bagaimana mereka dapat ditempatkan (stack up) pada tempat produk-produk yang sudah ada.

4. Tracking Consumer Perceptions

Product maps adalah cara yang paling ideal untuk dapat menyelidiki dan mengikuti jejak (track) dalam persepsi konsumen dari waktu ke waktu.

5. Identifying Differences Among Groups Perusahaan selalu ingin mengetahui secara jelas perbedaan yang terdapat dalam masyarakat (contoh; pengguna dan non pengguna, laki-laki dan perempuan d11.) dalam merasakan atau menilai produknya secara berbeda. Product maps merupakan salah satu jalan atau metode yang paling sesuai jika terjadi perbedaan persepsi dalam kelompok yang berbeda.

Terdapat tiga konsep dasar pada analisis positioning (perceptual mapping) yaitu
1. Differentiation, penciptaan perbedaan secara nyata ataupun tidak nyata dalam satu atau dua dimensi kunci (keys dimensions) antara focal product dan pesaing-pesaing utamanya.

2. Positioning, sejumlah stategi yang dibangun dan diterapkan perusahaan untuk memastikan diference produk menempati posisi yang jelas dan tepat pada benak konsumen.

3. Mapping, sebuah teknik yang memudahkan manejemen melakukan strategi differentiation dan sekaligus positioning dengan membantu memvisualisasi-kan struktur persaingan pasar berdasarkan penilaian persepsi konsumen.

\section{METODE PENELITIAN / METHODS}

Data penelitian ini berasal dari perawat perawat di RS Siti Khodijah Sepanjang dan RSIA Siti Aisyah Pacarkeling Surabaya dengan Populasi yang diteliti adalah semua perawat yang berdinas di ruang anak. Pengambilan sampel dilakukan pada bulan Mei-Juni 2019. Sampel diambil secara total dari perawat-perawat anak yang telah bekerja minimal 2 tahun. Sebelumnya dilakukan survey pendahuluan terlebih dahulu untuk mengidentifikasi variabel yang lebih cocok dari kuesioner yang telah dibuat oleh peneliti serta Untuk menentukan ukuran sampel yang harus diambil. Sampel awal yang diambil adalah sebesar 13 responden (perawat) secara proporsional yaitu :

RS Siti Khodijah Sepanjang : 8 responden (42\%)

Klinik Bersalin Ibu dan Anak Siti aisyah Pacarkeling Surabaya: 5 responden (38\%)

Hal ini dari pertimbangan survey awal yang ditemukan bahwa kedua rumah sakit memiliki budaya kerja yang sama dan RS Siti khodijah memiliki pelanggan non BPJS maupun BPJ, S sedangkan Klinik bersalin Ibu dan Anak Siti Aisyah 
Pacarkeling Surabaya melayani pelanggan non BPJS. Kuisioner tentang atribut produk diberikan kepada 100 pasien pelanggan RS yang terbagi pada 65 responden berasal dari RS terakreditasi dengan karakteristik pasien BPJS dan 35 responden berasal dari Klinik bersalin ibu dan anak dengan karakteristik non BPJS.

Pengukuran variable - variable penelitian yang digunakan dalam penelitian ini adalah skala pengharkatan verbal [Thomas

- Angka 4 menunjukkan agak setuju/memuaskan

- Angka 5 menunjukkan sangat setuju/memuaskandiikuti dengan pernyataan terbuka tiap responden dalam Fokus Group Diskusi bersama perawat.

Selanjutnya Kategori angka 1, 2 dan 3 digunakan untuk diberikan skoring 1 yang bermakna positif tidak menyetujui pertanyaan, sedangkan untuk kategori angka 4 dan 5 digunakan untuk diberikan skoring 0 yang bermakna negatif menyetujui pertanyaan.

Adapun varibel karakteristik demografi adalah sebagai berikut:

1. Type RS :

Untuk Mengetahui karakteristik pelanggan berdasarkan type Rumah Sakit
a. Terakreditasi
b. Proses Akreditasi

2. Karakteristik pelanggan Rumah Sakit :
a. Penghasilan menengah kebawah $<3.800 .000$
b. Penghasilan menengah 3.800.000-5.000.000
c. Penghasilan menengah ke atas 5.000.000-10.000.000
d. Penghasilan kelas atas $>10$ juta.
Karakteristik psikografi para pengguna di Rumah sakit ini diidentifikasi dengan beberapa variabel antara lain :

1. Pasien BPJS

2. Pasien Non BPJS
C.Kinnear/James R.Taylor 1997 ] Dalam model penskalaan ini responden diminta menunjukkan posisi mereka dalam kategori kategori yang diidentifikasikan secara verbal yaitu :

- Angka 1 menunjukkan sangat tidak setuju/memuaskan

- Angka 2 menunjukkan kurang setuju/memuaskan

- Angka 3 menunjukkan biasa

Untuk melakukan segmentasi pasar perlu diketahui bagaimana keinginan pasar terhadap suatu produk yang akan diluncurkan karena setiap pelangggan rumah sakit berpotensi menjadi pasar tersendiri. Indikasi yang dapat dianalisis untuk mengetahui bagaimana segmentasi dari pembeli dapat dilihat dari preferensinya terhadap atribut atribut yang berkaitan dengan produk yang dijual. Ketika memutuskan untuk membeli sebenarnya palanggan Rumah sakit tidak sekeder mempertimbangkan keputusannya semata - mata karena faktor barang tetapi keputusan tersebut sangat dipengaruhi oleh atribut - atribut yang melingkupinya antara lain sebagai berikut tentang manfaat yang ada yaitu menccegah resiko injury, resiko infeksi dann menurunkan dampak hospitalisasi

Untuk melakukan posisioning produk harus bisa didefinisikan oleh konsumen atas dasar atribut - atribut yang bisa ditempatkan dalam pikiran konsumen. Atribut - atribut tersebut berupa harga, produk penggunaan dan manfaat produk.

\section{HASIL PENELITIAN / RESULTS}

Transformasi data ordinal ke dalam data interval menggunakan metode rating yang dijumlahkan yang disebut sebagai penskalaan model likert Langkah - langkah dalam menstransformasi data adalah sebagai berikut : 
1. Menghitung frekuensi dari jawaban responden

2. Menetukan proporsi dengan membagi frekuensi tiap kategori dengan banyaknya responden

3. Menghitung frekuensi kumulatif untuk setiap kategori dengan menjumlahkan proporsi kategori pada semua kategori sebelumnya

4. Menghitung titik tengah proporsi kumulatif untuk setiap kategori dengan menjumlahkan setengah proporsi dalam kategori tersebut pada proporsi kumulatif sebelumnya.

5. Menentukan nilai $\mathrm{z}$ dari tabel distribusi normal berdasarkan bedasarkan nilai titik tengah proporsi kumulatif. Nilai $\mathrm{Z}$ merupakan titik letak setiap kategori respon disepanjang interval data yang berskala inteval.

Sehingga data mentah yang berskala ordinal dari penelitian tidak digunakan sedangkan, data yang digunakan dalam analisis ini adalah data ordinal yang telah ditransformasi dengan metode rating yang dijumlahkan segaimana langkah langkah transformasi yang telah dijelaskan di atas.

Dalam penelitian terdapat 100 responden yang dijadikan obyek penelitian yang memiliki karakteristik tertentu yang akan dijadikan pertimbangan dalam pengolahan data maupun dalam pengambilan keputusan. Oleh karena itu selanjutnya akan dilakukan analisis deskripsi untuk mengetahui karakteristik Deskripsi datanya adalah sebagai berikut :

\section{Karakteristik demografi}

Variabel - variabel demografik seringkali bekaitan erat dengan kebutuhan, keinginan dan tingkat pemakaian konsumen, selain itu besarnya sasaran pasar secara terukur bisa dilihat dari karakteristik demografi konsumen. Oleh karena itu akan dijelaskan deskripsi karakteristik demografi pada tabel berikut :

Tabel 3 Karakteristik demografi

\begin{tabular}{|c|c|c|c|c|}
\hline Variabel & Rincian karakteristik & jumlah & prosentase & kumulatif \\
\hline \multicolumn{5}{|l|}{ Type RS } \\
\hline & Akreditasi & 1 & 50,0 & 50,0 \\
\hline & Proses Akreditasi & 1 & 50,0 & 50,0 \\
\hline \multicolumn{5}{|l|}{ Penghasilan } \\
\hline \multirow[t]{4}{*}{ pelanggan } & $\begin{array}{l}\text { Penghasilan menengah } \\
\text { kebawah }<3.800 .000\end{array}$ & 5 & 5,0 & 5,0 \\
\hline & $\begin{array}{l}\text { Penghasilan menengah } \\
3.800 .000-5.000 .000\end{array}$ & 38 & 38,0 & 43,0 \\
\hline & $\begin{array}{ll}\text { Penghasilan } & \text { menengah } \\
\text { ke atas } & 5.000 .000- \\
10.000 .000 & \\
\end{array}$ & 10 & 9,0 & 52,0 \\
\hline & enghasilan kelas atas & 47 & 47,0 & 99,0 \\
\hline \multicolumn{5}{|l|}{ Type Pasien } \\
\hline BPJS & $\begin{array}{r}\text { Perawatan pasien } \\
\text { menggunakan BPJS } \\
\text { (dari Type RS } \\
\text { terakreditasi) }\end{array}$ & 65 & & \\
\hline
\end{tabular}


Balance Vol. XVII No. 2 | Juli 2019

\begin{tabular}{|l|r|r|r|r|}
\hline Non BPJS & $\begin{array}{r}\text { Perawatan Pasien dengan } \\
\text { biaya Sendiri/Pasien } \\
\text { Umum }\end{array}$ & 35 & 50,0 & 100,0 \\
\hline
\end{tabular}

\section{Karakteristik Psikografi}

Kelas sosial, gaya hidup yang berbeda menunjukkan karakteristik psikografi yang berbeda dan seringkali karakteristik demografi yang sama tidak menunjukkan psikografi yang sama. Pada tabel berikut akan ditampilkan

\section{Segmentasi}

Tujuan sebenarnya dalam melakukan segmentasi pelanggan adalah untuk mengetahui apa yang melatarbelakangi pelanggan membeli sebuah produk. Hal - hal yang melatarbelakangi itulah yang merupakan preferensi pelanggan ketika membuat keputusan untuk membeli. Sehingga dalam penelitian ini kita akan melihat bagaimana kelompok - kelompok pelanggan yang terbentuk berdasarkan preferensi terhadap atribut - atribut produk sarang infus

Tabel hasil crosstabulasi karakteristik psikografi dengan hasil atribut produk sarang infus

\begin{tabular}{|c|c|c|c|c|c|c|c|c|c|}
\hline Variabel & $\begin{array}{l}\text { Harga } \\
\text { mahal }\end{array}$ & $\begin{array}{l}\text { Hara } \\
\text { murah }\end{array}$ & Total & $\begin{array}{l}\text { Penggunaan } \\
\text { produk } \\
\text { mudah }\end{array}$ & $\begin{array}{l}\text { Penggunaan } \\
\text { produk } \\
\text { sulit }\end{array}$ & Total & $\begin{array}{l}\text { Manfaat } \\
\text { produk } \\
\text { sedikit }\end{array}$ & $\begin{array}{l}\text { Manfaat } \\
\text { produk } \\
\text { banyak }\end{array}$ & Total \\
\hline $\begin{array}{l}\text { Type RS } \\
\text { (terakreditasi) }\end{array}$ & 54 & 11 & 65 & 63 & 2 & 65 & 11 & 54 & 65 \\
\hline $\begin{array}{ll}\text { Type } & \text { RS } \\
\text { Proses } & \\
\text { Akreditasi } & \end{array}$ & 7 & 28 & 35 & 31 & 4 & 35 & 2 & 43 & 35 \\
\hline Total & 61 & 39 & 100 & 94 & 6 & 100 & 13 & 97 & 100 \\
\hline $\begin{array}{l}\text { Penghasilan } \\
\text { menengah } \\
\text { kebawah < } \\
3.800 .000\end{array}$ & 5 & 0 & 5 & 5 & 0 & 5 & 0 & 5 & 5 \\
\hline $\begin{array}{l}\text { Penghasilan } \\
\text { menengah } \\
3.800 .000- \\
5.000 .000\end{array}$ & 16 & 22 & 38 & 30 & 8 & 38 & 13 & 25 & 38 \\
\hline $\begin{array}{l}\text { Penghasilan } \\
\text { menengah } \\
\text { ke atas } \\
5.000 .000- \\
10.000 .000\end{array}$ & 0 & 10 & 10 & 10 & 0 & 10 & 1 & 9 & 10 \\
\hline $\begin{array}{l}\text { Penghasilan } \\
\text { kelas atas } \\
>10 \text { juta }\end{array}$ & 4 & 43 & 47 & 41 & 6 & 47 & 2 & 45 & 47 \\
\hline Total & 25 & 75 & 100 & 86 & 14 & 100 & 16 & 84 & 100 \\
\hline $\begin{array}{r}\text { Perawatan } \\
\text { pasien } \\
\text { menggunakan } \\
\text { BPJS } \\
\end{array}$ & 54 & 11 & 65 & 63 & 2 & 65 & 11 & 54 & 65 \\
\hline $\begin{array}{r}\text { Perawatan } \\
\text { Pasien dengan } \\
\text { biaya } \\
\text { Sendiri/Pasien } \\
\text { Umum } \\
\end{array}$ & 7 & 28 & 35 & 31 & 4 & 35 & 2 & 43 & 35 \\
\hline Total & 61 & 39 & 100 & 94 & 6 & 100 & 13 & 97 & 100 \\
\hline
\end{tabular}




\section{DAFTAR PUSTAKA / BIBLIOGRAPHY}

Supranto, J (1994), Metode Riset dan Aplikasinya di dalam Riset Pemasaran, Lembaga Penerbit Fakultas Ekonomi Universitas Indonesia.

Kasali, Rheinald, (1998), Membidik Pasar Indonesia : Segmentasi, Targeting dan Positioning, Gramedia Pustaka Utama, Jakarta.

Kotler, Philip, 2005, manajemen Pemasaran, Jilid 1, Edisi 11, Terjemahan PT Indeks, Jakarta.

Kotler, P. and Armstrong, G (2005), Dasar-Dasar Pemasaran, Terjemahan oleh Wilhelmus W. B, Intermedia Jakarta dan Simon \& Schuster (Asia) Pte. Ltd., Singapore.

Simamora, Bilson. (2001). Remarketing for Bussiness recovery, PT Gramedia Pustaka Utama, Jakarta 